\title{
ANALISIS MINAT MENGGUNAKAN BRI MOBILE (Survei Pada Nasabah Bank Rakyat Indonesia (Persero) Tbk. Kota Sukabumi)
}

\author{
Larasati Dewi Hermawan ${ }^{1}$ \\ Kokom Komariah ${ }^{2}$ \\ R. Deni Muhammad Danial ${ }^{3}$
}

\author{
Fakultas Ilmu Administrasi dan Humaniora Universitas Muhammadiyah \\ Sukabumi, Jawa Barat, Indonesia ${ }^{1,2,3}$ \\ Email:larasatidewi069@ummi.ac.id ${ }^{1}$, ko2mpuspa@ummi.ac.id ${ }^{2}$, \\ rdmdanial043@ummi.ac.id ${ }^{3}$
}

\begin{abstract}
The research aims to measure how much influence the perception of ease of use, perceived usefulness and perceived security of interest in using. The variables used in this study are perceived ease of use (X1), perceived usefulness (X2), perceived security (X3) and interest in using (Y). The method used in this study uses a purposive sampling method by distributing questionnaires to 200 respondents of Bank Rakyat Indonesia customers in Sukabumi City. The analysis technique used is multiple linear regression measuring the effect partially and simultaneously. The results obtained indicate a positive and significant effect between perceived ease of use, perceived usefulness and perceived security of interest in using.
\end{abstract}

Keywords: Perceived Ease of Use; Benefit Perception; Security Perceptions and Interests in Using.

\begin{abstract}
ABSTRAK
Penelitian bertujuan untuk mengukur seberapa besar pengaruh persepsi kemudahan penggunaan, persepsi manfaat dan persepsi keamanan terhadap minat menggunakan. Variabel yang digunakan dalam penelitian ini yaitu persepsi kemudahan penggunaan (X1), persepsi manfaat (X2), persepsi keamanan (X3) dan minat menggunakan (Y). Adapun metode yang digunakan dalam penelitian ini menggunakan metode purposive sampling dengan melakukan penyebaran kuesioner kepada 200 responden nasabah Bank Rakyat Indonesia Kota Sukabumi. Teknik Analisa yang digunakan yaitu regresi linear beganda mengukur pengaruh secara parsial dan pengaruh secara simultan . Hasil yang didapatkan menunjukkan adanya pengaruh yang positif dan signifikan antara persepsi kemudahan penggunaan,persepsi manfaat dan persepsi keamanan terhadap minat menggunakan.
\end{abstract}

Kata Kunci : Persepsi Kemudahan Penggunaan; Persepsi Manfaat; Persepsi Keamanan dan Minat Menggunakan. 


\section{PENDAHULUAN}

Pertumbuhan teknologi informasi berkembang sangat pesat. Teknologi mengiringi kehidupan manusia dan saling memenuhi kebutuhan satu dengan lainnya. Salah satu kemudahan yang dihasilkan dengan kemajuan itu adalah internet, saat ini perkembangan internet di Indonesia terjadi sangat cepat. Hasil riset APJJI menunjukkan yang telah menggunakan internet pada tahun 2018 berjumlah 171,17 juta orang. Hal tersebut mengalami peningkatan dari tahun sebelumnya yaitu tahun 2017 berjumlah 143,26 juta orang dengan data tersebut, bisa dikatakan bahwa internet telah menjadi kebutuhan masyarakat yang sangat penting (APJII, 2018).

Indrustri perbankan telah mengembangkan berbagai saluran perbankan elektronik untuk mengikuti perkembangan teknologi yang disesuaikan dengan kebutuhan masyarakat saat ini. Salah satu kemudahan yang diciptakan oleh perbankan di era digital ini adalah meluncurkan layanan aplikasi mobile banking, yang menyediakan berbagai layanan keuangan bagi nasabah melalui teknologi informasi dan komunikasi.

Salah satu perbankan yang meluncurkan aplikasi ini adalah PT Bank Rakyat Indonesia (Persero) Tbk meluncurkan fasilitas layanan mobile banking yang bernama "BRI Mobile" Layanan elektronik ini lengakap dan menarik dengan menu transaksi, dapat dinikmati melalui ponsel pintar atau smartphone. Layanan ini memenuhi kebutuhan masyarakat ditengah perkembangan teknologi. (cermati.com, 2019). Manusia akan menggunakan produk pasti menilai dengan berbagai pertimbangan dalam menggunakan suatu produk tertentu. Dengan adanya 
minat pada seseorang yang akan menentukan menggunakan atau tidak menggunakan produk tersebut.

Meskipun banyak kemudahan dan manfaat yang akan didapat bagi pengguna ketika menggunakan mobile banking namun pada kenyataanya tidak selalu berjalan dengan antusias nasabah untuk menggunakannya. Berdasarkan riset Strategi Nasional Keuangan Inklusif menyatakan 70,2\% masyarakat dewasa mempunyai handphone / telepon genggam. Akan tetapi penggunannya untuk mobile banking masih kecil. Hanya 24,5\% masyarakat dewasa yang bisa menjalankan transaksi keuangan menggunakan handphone / telepon genggam (Lidwina, 2019).

Permasalahan bagaimana nasabah dapat menerima dan memanfaatkan layanan BRI Mobile ini secara maksimal dapat dijelaskan dengan model TAM. Yang didalamnya menggunakan persepsi kemudahan penggunaan dan persepsi manfaat, sebuah sistem diciptakan untuk mempermudah dan bermanfaat untuk pemakainya, semakin nasabah merasa menggunakannya mudah dan memberi manfaat maka sistem tersebut akan sering digunakan. Dan yang terakhir variabel tambahan yaitu persepsi keamanan, nasabah masih beranggapan sebuah sistem tersebut rumit dan meragukan keamanan dari sistem tersebut . Seperti halnya dalam penelitian yang telah dilakukan oleh (Rizky, Yasa, \& Wahyuni, 2018) membuktikan persepsi kemudahan berpengaruh tehadap minat menggunakan, bertentangan dengan (Saputri, 2018) membuktikan tidak adanya pengaruh terhadap minat menggunakan, penelitian (Rahyuni, 2019) membuktikan persepsi manfaat berpengaruh terhadap minat menggunakan, bertentangan (Anggraeni, 2019) yang 
membuktikan tidak berpengaruh terhadap minat menggunakan, penelitian (Oktabriantono, Sulindawati, \& Dewi, 2017) menunjukkan bahwa persepsi keamanan berpengaruh terhadap minat menggunakan, bertentangan dengan (Afghani \& Yulianti, 2017) tidak berpengaruh terhadap minat menggunakan. Penelitian ini tentang layanan BRI Mobile oleh karena itu penelitian di tujukkan kepada nasabah Bank Rakyat Indonesia yang belum dan telah menggunakan layanan BRI Mobile.

TAM singkatan dari Technologi Aceptance Model yang merupakan "model penerimaan teknologi yang dibuat untuk mengetahui dan memahami faktor penerimaan teknologi” (Jogiyanto, 2008).

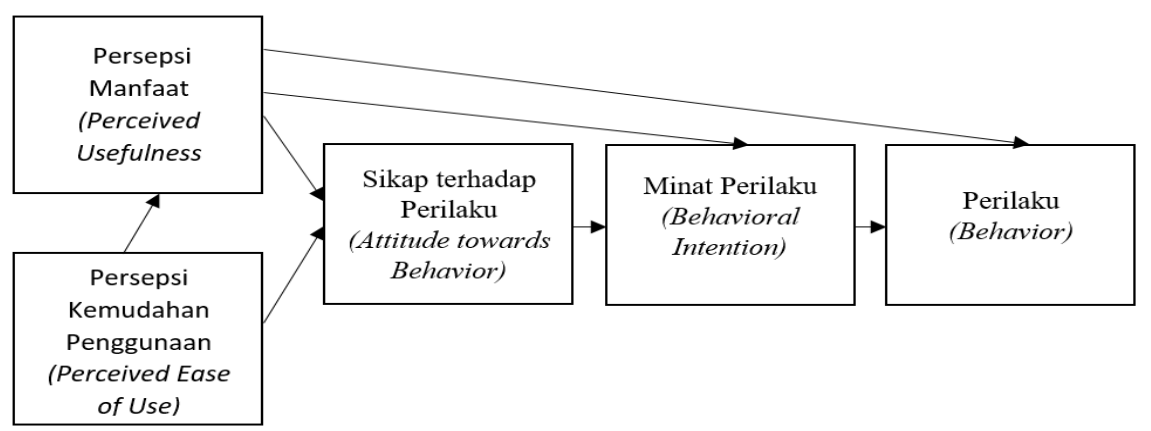

\section{Gambar 1. \\ Technology Acceptance Model}

Persepsi Kemudahan Penggunaan merupakan "tingkat seseorang merasa yakin bahwa meggunakan suatu teknologi tidak memerlukan usaha yang besar” ("is the extent to which a person belives that using a technology will be free of effort”) (Aidar, 2018; Amanullah, 2014; Jogiyanto, 2008).Dimensi persepsi kemudahan penggunaan yang digunakan (Sari, 2019) adalah : “1) Mudah dipelajari, 2) mudah digunakan, 3) Jelas dan mudah dimengerti, 4) menjadi terampil”. 
Penelitian terdahulu (Wulandari, 2017) membuktikan "sebuah sistem dibuat untuk memberikan kemudahan bukan untuk mempersulit penggunanya,dengan demikian seseorang menggunakan sistem akan bekerja lebih mudah dibandingkan secara manual”. Sehingga adanya pengaruh positif dan signifikan antara persepsi kemudahan penggunaan terhadap minat menggunakan, serupa dengan hasil penelitian yang telah dilakukan oleh (Bagastia, 2018).

$\mathrm{H}_{1}=$ Persepsi Kemudahan Penggunaan berpengaruh positif dan signifikan terhadap Minat menggunakan.

Persepsi Manfaat merupakan "tingkat keyakinan individu dalam memakai suatu sistem tertentu akan menambah kemampuan pekerjaannya" ("as the extent to which a person belives that using a technology will enhance her or his performance”). (Aidar, 2018; Jogiyanto, 2008). Dimensi persepsi manfaat (Irmadhani, 2012) yang digunakan : “1) Penggunaan mampu meningkatan kinerja individu , 2) penggunaan sistem mampu menambah tingkat produktivitas individu, 3) penggunaan sistem mampu meningkatkan efektivitas individu, 4) penggunaan sistem bermanfaat bagi individu".

Penelitian terdahulu (Rahayu, 2019) membuktikan “jika seseorang merasa bahwa dengan menggunakan teknologi informasi dapat mendatangkan manfaat baik berupa peningkatan kinerja atau keuntungan bagi dirinya, maka dia akan menggunakannya". Sehingga adanya pengaruh positif dan signifikan antara persepsi manfaat terhadap minat menggunakan sejalan denegan hasil penelitian yang dilakukan oleh (Laksana, 2015; Wibiadila, 2016). 
$\mathrm{H}_{2}=$ Persepsi Manfaat berpengaruh positif dan signifikan terhadap Minat Menggunakan

Persepsi keamanan didefinisikan sebagai " tingkat keyakinan seseorang atas terjaminnya keamanan sistem dapat melindungi atau menjaga informasi data pribadi dan menjamin keamanannya saat menggunakan sistem tersebut" (Ananda, 2019; Saptawati, 2018; Sari, 2019). Dimensi yang digunakan oleh (Fahmi \& Evanita, 2019) yakni : “1) Jaminan keamanan 2) Kerahasiaan Data”, lalu dimemsi ysng digunakan oleh (Sari, 2019) yakni : “1) Tidak khawatir memberikan informasi 2) Kepercayaan bahwa informasi dilindungi 3) Kepercayaan bahwa keamanan uang dalam alat elektronik terjamin pada saat bertransaksi", lalu dimensi yang digunakan oleh (Iliyin, 2020) yakni : “1) Aman 2) Resiko hilangnya data atau informasi kecil 3) Resiko pencurian kecil 4) Terjaminnya kerahasiaan".

Maka dimensi persepsi keamanan yang digunakan dalam penelitian ini ada empat yaitu : 1) Jaminan keamanan (Fahmi \& Evanita, 2019) 2) Kepercayaan bahwa informasi dilindungi (Sari, 2019) 3) Kepercayaan bahwa keamanan uang yanga ada didalam alat elektronik terjamin pada saat transaksi (Sari, 2019), 4) Resiko pencurian kecil (Iliyin, 2020).

Penelitian terdahulu (Nurhaliza, 2019) membuktikan "apabila tingkat keamanan tinggi dengan menjamin segala informasi pribadi pengguna aman maka pengguna akan merasa aman dan berminat menggunakan teknologi tersebut", sehingga adanya pengaruh positif dan signifikan antara persepsi keamanan 
terhadap minat menggunakan, sejalan dengan hasil penelitian yang telah dilakukan oleh (Nurhayati, Anam, \& Manalu, 2020; Oktabriantono et al., 2017).

$\mathrm{H}_{3}=$ Persepsi Keamanan berpengaruh positif dan signifikan terhadap Minat Menggunakan.

Minat menggunakan merupakan kecenderungan, keinginan, kegairahan yang tinggi atau rasa ketertarikan kepada suatu hal dan adanya kemauan yang timbul dari dalam individu tanpa ada yang memerintah terhadap sesuatu. Semakin kuat rasa ketertarikan maka semakin besarnya minat, dan sampai akhirnya timbul keinginan untuk menggunakan produk tersebut (Anwar, 2018; Wahyuningsih, 2019).

Adapun dimensi minat menggunakan yang digunakan oleh (Anwar, 2018) : “1) Keinginan menggunanakan 2) kesesuaian penggunaan dengan kebutuhan 3) Dukungan dalam menggunakan 4) keinginan merekomendasikan”, lalu dimensi yang digunakan oleh (Fahmi \& Evanita, 2019) yakni : “1) penggunaan 2) tetap menggunakan 3) merekomendasikan”, dan dimensi yang digunakan oleh (Saputri, 2018) yakni : “1) mencari informasi lebih lanjut tentang produk tersebut 2) mereferensikan produk tersebut kepada orang lain 3) yakin produk tersebut menjadi pilihan utama 4) berminat untuk menggunakan produk tersebut”.

Maka dimensi minat menggunakan yang dipakai : 1) Keinginan menggunakan (Anwar, 2018; Fahmi \& Evanita, 2019), 2) mencari informasi lebih lanjut tentang produk tersebut (Saputri, 2018) 3) Dukungan dalam menggunakan (Anwar, 2018) 4) merekomendasikan (Anwar, 2018; Fahmi \& Evanita, 2019). 


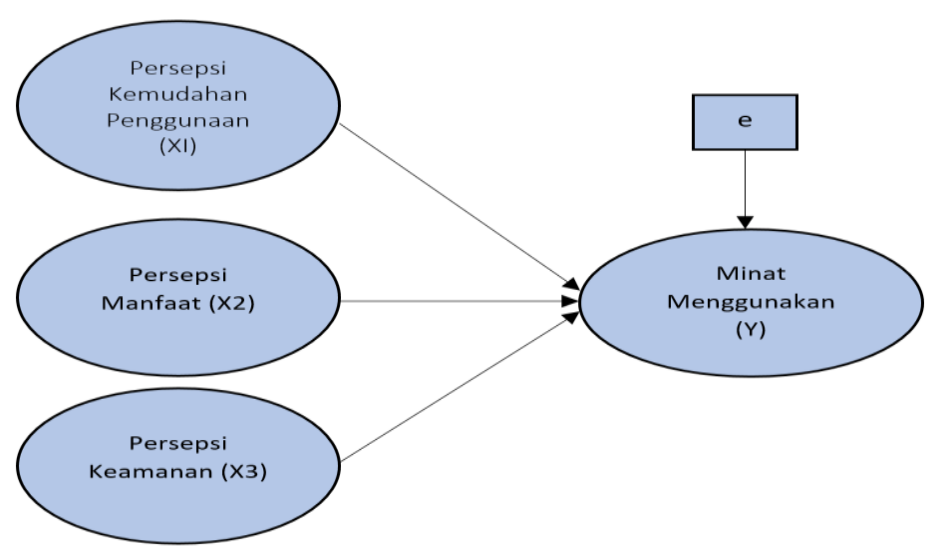

Gambar 2.

Model Penelitian

\section{METODE PENELITIAN}

Masyarakat Kota Sukabumi menjadi populasi penelitian, yang termasuk kedalam sampel penelitian yakni nasabah Bank Rakyat Indonesia. Menggunakan metode penelitian kuantitatif. Dengan Teknik pengambilan data menggunakan purposive sampling dengan kriteria responden adalah nasabah Bank Rakyat Indonesia dan mengetahui tentang layanan BRI Mobile, penyebaran kuesioner dilakukan kepada 200 responden. Teknik analisis data menggunakan analisis regresi linear berganda dan pengujian model hipotesis yaitu uji secara parsial dan uji secara simultan.

\section{HASIL DAN PEMBAHASAN}

Uji kelayakan model dilakukan "untuk mengetahui model yang dianalisis memiliki tingkat kelayakan yang layak atau tidak" (Ferdinand, 2014). Adapun hasil pengolahan data ditunjukan pada Tabel 1. 
Tabel 1.

Hasil Uji F

\begin{tabular}{|c|c|c|c|c|c|c|}
\hline \multicolumn{7}{|c|}{ ANOVA } \\
\hline \multicolumn{2}{|l|}{ Model } & $\begin{array}{l}\text { Sum of } \\
\text { Squares }\end{array}$ & df & $\begin{array}{l}\text { Mean } \\
\text { Square }\end{array}$ & $\mathbf{F}$ & Sig \\
\hline \multirow[t]{3}{*}{1} & Regression & 1276.095 & 3 & 425.365 & 101.786 & $.000^{\mathrm{b}}$ \\
\hline & Residual & 819.085 & 196 & 4.179 & & \\
\hline & Total & 2095.180 & 199 & & & \\
\hline a. & \multicolumn{6}{|c|}{ Dependent Variable : Minat Menggunakan } \\
\hline b. & \multicolumn{6}{|c|}{$\begin{array}{l}\text { Preditors : (Constant), Persepsi Keamanan, Persepsi Manfaat, Persepsi } \\
\text { Kemudahan Penggunaan }\end{array}$} \\
\hline
\end{tabular}

Menunjukkan bahwa nilai $F_{h i t u n g}$ sebesar 101.786 maka $F_{\text {hitung }}$ lebih besar dari $\mathrm{F}_{\text {tabel }}$ yakni $101.786>2,65$ serta nilai regresi memiliki tingkatan $0,000<0,05$ maka dapat disimpulkan bahwa adanya pengaruh simultan variabel independen terhadap variabel dependen sebagai hipotesis dapat diterima.

Tabel 2.

Uji Koefisien Determinasi

\begin{tabular}{|c|c|c|c|c|}
\hline \multicolumn{5}{|c|}{ Model Summary } \\
\hline Model & $\mathbf{R}$ & R Square & Adjusted R & $\begin{array}{l}\text { Std Error of } \\
\text { the Estimate }\end{array}$ \\
\hline 1 & $.780^{\mathrm{a}}$ & .609 & .603 & 2.04426 \\
\hline $\begin{array}{ll}\text { a. } & \text { Predi } \\
& \text { Pengs }\end{array}$ & stant), & Keamanan, $\mathrm{P}$ & psi Manfaat, Pe & psi Kemudahan \\
\hline
\end{tabular}

Perolehan nilai korelasi sebesar 0,780 dan menunjukkan nilai koefisien determinasi 0,603. Dan nilai R Square sebesar 0,609 maka terdapat pengaruh variabel independent yaitu persepsi kemudahan penggunaan, persepsi manfaat dan persepsi keamanan terhadap variabel dependent yaitu minat menggunakan sebesar $60,9 \%$ dan sisanya $39,1 \%$ dipengaruhi oleh faktor lain yang tidak diteliti. 
Analisis Regresi berganda merupakan "analisis statistik yang menghubungkan antara dua variabel atau lebih dan membuat perkiraan nilai $\mathrm{X}$ atas Y” (Lupiyoadi \& Ikhsan, 2015) dengan pengolahan data IBM SPSS 24.

Tabel 3.

Hasil Regresi Liniear Berganda \& Uji T

\begin{tabular}{|c|c|c|c|c|c|c|}
\hline \multirow[t]{2}{*}{ Model } & & \multicolumn{2}{|c|}{$\begin{array}{l}\text { Unstadarized } \\
\text { Coefficients }\end{array}$} & \multirow{2}{*}{$\begin{array}{c}\begin{array}{c}\text { Standarize } \\
\text { d } \\
\text { Coefficients }\end{array} \\
\text { Beta }\end{array}$} & \multirow[b]{2}{*}{$\mathbf{t}$} & \multirow[b]{2}{*}{ sig } \\
\hline & & B & $\begin{array}{l}\text { Std.Er } \\
\text { ror }\end{array}$ & & & \\
\hline \multirow[t]{4}{*}{1} & (Constant) & 1.395 & 814 & & 1.713 & 088 \\
\hline & $\begin{array}{l}\text { Persepsi Kemudahan } \\
\text { Penggunaan (X1) }\end{array}$ & 355 & 063 & 426 & 5.606 & 000 \\
\hline & Persepsi Manfaat (X2) & 236 & 074 & 233 & 3.190 & 002 \\
\hline & $\begin{array}{l}\text { Persepsi Keamanan } \\
\text { (X3) }\end{array}$ & 209 & 073 & 195 & 2.848 & 005 \\
\hline
\end{tabular}

Sumber : data diolah,2020

Perolehan menunjukkan nilai constanta (a) sebesar 1.395 dengan nilai persepsi kemudahahan penggunaan 0,355 nilai persepsi manfaat 0,236 dan nilai persepsi keamanan 0,209 maka hal ini menunjukkan adanya pengaruh positif sehingga muncul persamaan regresi liniear berganda dengan rumus (Lupiyoadi \& Ikhsan, 2015) $: Y=a+b_{1} X_{1}+b_{2} X_{2}+$ maka $Y=1.359+0,355+0,236+0,209$

Hipotesis pertama memiliki nilai $\mathrm{T}_{\text {hitung }}$ sebesar $5.606>1,97214 \mathrm{~T}_{\text {tabel }}$ dan dengan nilai signifikan $0,000<0,05$ yang artinya $\mathrm{H}_{1}$ ada pengaruh positif dan signifikan antara persepsi kemudahan penggunaan terhadap minat menggunakan. Sejalan dengan hasil penelitian (Bagastia, 2018) oleh karena itu "sebuah sistem dibuat untuk memberikan kemudahan bukan untuk mempersulit penggunanya, dengan demikian seseorang menggunakan sistem akan bekerja lebih mudah dibandingkan secara manual" (Wulandari, 2017). 
Hipotesis kedua memiliki nilai $\mathrm{T}_{\text {hitung }} 3.190>$ 1,97214 dan nilai signifikan $0,002<0,05$ yang artinya $\mathrm{H}_{2}$ ada pengaruh yang positif dan signifikan antara persepsi manfaat terhadap minat menggunakan. Serupa dengan hasil penelitian (Laksana, 2015) oleh karena itu" jika seseorang merasa bahwa dengan menggunakan teknologi informasi mendatangkan manfaat baik berupa peningkatan kerja, maka ia akan menggunakannya" (Rahayu, 2019).

Hipotesis ketiga memiliki nilai $\mathrm{T}_{\text {hitung }} 2.848>1,97214$ dan nilai signifikan $0,005<0,05$ yang artinya $\mathrm{H}_{3}$ ada pengaruh yang positif dan signifikan antara persepsi keamanan terhadap minat menggunakan. Sejalan dengan hasil penelitian (Nurhayati et al., 2020) oleh karena itu "apabila tingkat keamanan tinggi dengan menjamin segala informasi pribadi pengguna aman maka pengguna akan merasa aman dan berminat menggunakan produk tersebut" (Nurhaliza, 2019).

\section{SIMPULAN DAN SARAN}

Berdasarkan penelitian diatas, maka disimpulkan untuk menjawab pertanyaan penelitian. Dengan menggunakan Teknik analisis linear berganda menunjukkan adanya pengaruh variabel independent yang terdiri dari tiga varibel yaitu persepsi kemudahan penggunaan (X1), persepsi manfaat (X2), dan persepsi keamanan (X3) terhadap variabel dependent yaitu minat menggunakan (Y). Dan hasil uji hipotesis secara parsial dan simultan menyatakan adanya hubungan positif dan signifikan secara parsial X1,X2,dan X3 terhadap Y.

Penelitian ini menggunakan variabel minat menggunakan, untuk penelitian selanjutnya peneliti menyarankan menggunakan variabel minat menggunakan 
ulang sebagai variabel dependen, lalu karena 39,1\% penelitian dipengaruhi oleh variabel lain maka peneliti menyarankan menggunakan variabel independen yang lain yang belum di teliti pada penelitian ini. Untuk perusahaan peneliti menyarankan agar lebih di tingkatkan pengenalan tentang layanan digital banking seperti mobile banking atau BRI Mobile kepada nasabah, meningkatkan kemudahan sistem layanan, dan keamanan sistem pada layanan BRI Mobile agar nasabah tertarik dan percaya keamanan uang dan data informasi nasabah terlindungi.

\section{REFERENSI}

Afghani, M. F., \& Yulianti, E. (2017). Pengaruh Kepercayaan, Keamanan, Persepsi Risiko, Serta Kesadaran Nasabah Terhadap Adopsi E-Banking Di Bank Bri Surabaya. Journal of Business \& Banking, 6(1), 113-128. https://doi.org/10.14414/jbb.v6i1.898

Aidar, A. A. N. (2018). Pengaruh persepsi manfaat,kemudahan penggunaan dan kepercayaan terhadap sikap penggunaan layanan mobile banking. Retrieved from http://eprints.iain-surakarta.ac.id/2457/

Amanullah, B. (2014). Kepercayaan Terhadap Sikap Positif Penggunaan Layanan Mobile Banking ( Survey Pada Nasabah Bank BCA Semarang ). Retrieved from http://eprints.undip.ac.id/43009/

Ananda, H. R. (2019). Persepsi Kegunaan, Persepsi Kemudahan Menggunakan, Persepsi Manfaat, Dan Persepsi Kompatibilitas Terhadap Intensi Menggunakan Layanan Mobile Payment. Retrieved from https://dspace.uii.ac.id/handle/123456789/14180

Anggraeni, S. (2019). Persepsi Kemanfaatan terhadap Minat Nasabah Menggunkan Mobile Banking dengan Kepercayaan sebagai Variabel Intervening. Retrieved from http://e-repository.perpus.iainsalatiga.ac.id/6394/

Anwar, M. F. (2018). Pengaruh Persepsi Kegunaan,Kepercayaan dan Risiko terhadap Minat Menggunakan Mobile Banking. Institut Agama Islam Negeri Salatiga.

APJII. (2019). Pengguna Internet Di Indonesia 2018 Bertambah 28 juta. Retrieved from https://databoks.katadata.co.id/datapublish/2019/05/16/penggunainternet-di-indonesia-2018-bertambah-28-juta\# 
Bagastia, M. I. (2018). Pengaruh Kemudahan, Kenyamanan, Dan Risiko Terhadap Minat Menggunakan Mobile Banking Dengan Kepercayaan Sebagai Variabel Intervening. Retrieved from http://e-repository.perpus.iainsalatiga.ac.id/4772/

Cermati.com. (2019). BRI Mobile dan SMS banking BRI serta cara aktivasi dan menggunakannya. Retrieved from https://www.cermati.com/artikel/brimobile-dan-sms-banking-bri-serta-cara-aktivasi-dan-menggunakannya

Fahmi, Z., \& Evanita, S. (2019). Pengaruh Iklan dan Perceived Security terhadap Minat Transaksi Pebayaran Berbasis e-Payment dengan Sikap sebagai Variabel Intervening pada Masyarakat di Kota Padang. Jurnal Kajian Manajemen Dan Wirausaha, 01(02), 83-96.

Ferdinand, A. (2014). Metode Penelitian Manajemen Pedoman penelitian untuk Penulisan skripsi Tesis dan Disertasi Ilmu Manajemen. Semarang: Badan Penerbit Universitas Diponegoro

Iliyin, A. (2020). Pengaruh Persepsi Kemudahan Penggunaan dan Persepsi Keamanan Terhadap Keputusan Penggunaan OVO PT Visionet Data International (Studi Pada Pengguna OVO di Kota Surakarta). Jurnal Ilmu Administrasi Bisnis, 9(1), 85-92.

Irmadhani, M. A. N. (2012). Pengaruh persepsi kebermanfaatan, persepsi kemudahan penggunaan dan Computer Self Efficacy, Terhadap Penggunaan Online Banking Pada Mahasiswa S1 Fakultas Ekonomi Universitas Negeri Yogyakarta. Kajian Pendidikan Akuntansi Indonesia, 3(1), 1-20.

Jogiyanto. (2008). Sistem Informasi Keperilakuan. Yogyakarta: C.V Andi Offset.

Laksana, G. (2015). Pengaruh Persepsi Kemanfaatan, Persepsi Kemudahan Penggunaan, Persepsi Resiko Dan Persepsi Kesesuaian Terhadap Minat Menggunakan Mobile Banking (Studi Pada Nasabah Bank Rakyat Indonesia (BRI) Kantor Cabang Rembang, Jawa Tengah). Jurnal Administrasi Bisnis S1 Universitas Brawijaya, 26(2), 1-8.

Lidwina, A. (2019). Hanya 24,5\% Penduduk Dewasa yang Pakai Ponsel Untuk Transaksi Keuangan. Retrieved from https://databoks.katadata.co.id/datapublish/2019/11/15/hanya-245-pendudukdewasa-gunakan-telepon-seluler-untuk-transaksi-keuangan

Lupiyoadi, R., \& Ikhsan, R. B. (2015). Praktikum Metode Riset Bisnis. Jakarta Selatan: Salemba Empat.

Nurhaliza, S. L. (2019). Pengaruh Persepsi Kemudahan, Manfaat, Resiko Dan Keamanan Terhadap Minat Penggunaan E-Money Di Kalangan Mahasiswa Di Yogyakarta. Retrieved from https://dspace.uii.ac.id/handle/123456789/18349

Nurhayati, Anam, H., \& Manalu, V. B. (2020). Persepsi Kegunaan,Persepsi Kemudahan, Keamanan dan Kerahasiaan, Kesiapan Teknologi Informasi Terhadap Intensitas Perilaku Dalam Penggunaan E-Filing. Jurnal GeoEkonomi ISSN-Elektronik, 11(1), 1-15. 
https://doi.org/doi.org/10.36277/geoekonomi

Oktabriantono, A. P., Sulindawati, N. luh G. E., \& Dewi, P. E. D. M. (2017). Pengaruh Persepsi Kebermanfaatan, Persepsi Kemudahan Penggunaan, Keamanan, dan Persepsi Risiko terhadap Penggunaan E-banking pada Mahasiswa S1 Fakultas Ekonomi Universitas Pendidikan Ganesha. E-Journal S1 Ak Universitas Pendidikan Ganesha, 8(2), 1-10.

Rahayu, P. R. (2019). Pengaruh Persepsi Kegunaan, Persepsi Kemudahan, Persepsi Kepercayaan, dan Persepsi Kenyamanan Terhadap Minat Penggunaan Mobile Banking (Universitas Islam Indonesia; Vol. 1). https://doi.org/10.1017/CBO9781107415324.004

Rahyuni. (2019). Pengaruh Persepsi Kemanfaatan dan Persepsi Kemudahan terhadap Minat Menggunakan Mobile Banking pada Masyarakat Boyolali. Retrieved from http://eprints.iain-surakarta.ac.id/4640/

Rizky, N., Yasa, I. N. P., \& Wahyuni, M. A. (2018). Pengaruh Persepsi Kemudahan Penggunaan, Kepercayaan, Dan Pengetahuan Terhadap Minat Menggunakan E-Banking Dalam Bertransaksi Pada Umkm Di Kecamatan Buleleng. JIMAT (Jurnal Ilmiah Mahasiswa Akuntansi), 9(2), 191-202.

Saptawati, Y. (2018). Pengaruh Persepsi Kemudahan, Keamanan \& Manfaat Mobile Banking Terhadap Kepuasan Nasabah Pada PT. Bank Rakyat Indonesia (Persero) Tbk Cabang Bulukumba. Retrieved from http://repository.stienobel-indonesia.ac.id/handle/123456789/297

Saputri, L. (2018). Pengaruh Persepsi Manfaat, Persepsi Kemudahan Penggunaan dan Persespi Risiko terhadap Minat Masyarakat Menggunakan Fasilitas Electronic Banking Bank Syariah dengan Kepercayaan sebagai Variabel Intervening (IAIN Salatiga; $\quad$ Vol. https://doi.org/10.1017/CBO9781107415324.004

Sari, I. (2019). Pengaruh Kemudahan,Manfaat Penggunaan Teknologi, Fitur Layanan Dan Keamanan,Terhadap Minat Menggunakan E-Money, Dengan Sikap Penggunaan Sebagai Variabel Intervening. Retrieved from http://erepository.perpus.iainsalatiga.ac.id/5989/

Wahyuningsih, S. A. (2019). Pengaruh Persepsi Kemudahan, Kemanfaatan Dan Risiko Terhadap Minat Nasabah Menggunakan Internet Banking Dengan Kepercayaan Sebagai Variabel Intervening. Retrieved from http://erepository.perpus.iainsalatiga.ac.id/5277/

Wibiadila, I. (2016). Pengaruh kegunaan, kemudahan, resiko, dan kualitas layanan terhadap minat nasabah dalam menggunakan mobile banking. Management Journal, 2(2), 1-13.

Wulandari, C. O. (2017). Pengaruh Kebermanfaatan, kemudahan penggunaan dan Persepsi Risiko terhadap Minat Bertransaksi Menggunakan Internet Banking. Retrieved from https://eprints.uny.ac.id/59902/ 